Furnaces, warm-air (equipped with oil-burners, vaporizing, pot-type)

U. S. DEPARTMENT OF COMMERCE HENRY A, WALLACE, Secretary

NATIONAL BUREAU OF STANDARDS

E. U. CONDON, Director

\title{
WARM-AIR FURNACES EQUIPPED WITH VAPORIZING POT-TYPE OIL BURNERS
}

(SECOND EDITION)

COMMERCIAL STANDARD CS104-46

Supersedes CS(E) 104-43

Effective Date for New Production From March 15, 1946

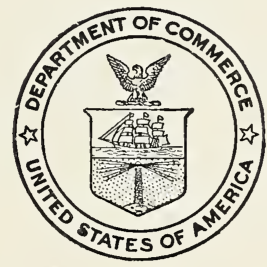

\section{A RECORDED VOLUNTARY STANDARD} OF THE TRADE

UNITED STATES

GOVERNMENT PRINTING OFFICE

WASHINGTON : 1946 


\title{
P R O M U L G A T I O N
}

of

COMMERCIAL STANDARD CS104-46

for

\begin{abstract}
WARM AIR FURNACES EQUIPPED WITH VAPORIZING POT - TYPE OIL BURNERS
\end{abstract}

\section{(Second Edition)}

On June 24, 1942, a representative conference of manufacturers adjusted and adopted a Proposed Commercial Standard for WarmAir Furnaces Equipped With Vaporizing Pot-Type Oil Burners, which had been in course of development and discussion in a series of meetings beginning July 14, 1941. The proposed standard was subsequently adjusted to suit composite written comment resulting from a circulation for that purpose on July 10 and 11, 1942, to users, distributors, installers, contractors, manufacturers, and testing laboratories. The adjusted draft was accepted by the trade and promulgated as Warm-Air Furnaces Equipped With Vaporizing Pot-Type Oil Burners, Commercial Standard (Emergency) CS(E)104-43.

On September 19, 1945, a revision submitted by various sources, and approved by the standing committee, was circulated for acceptance. Those concerned have since accepted and approved the revised standard as shown herein, for promulgation by the United States Department of Commerce, through the National Bureau of Standards.

The revised standard is effective for new production on March 15, 1946.

Promulgation recommended.

F. W. Reynolds,

Promulgated.

Acting Chief, Division of Trade Standards.

E. U. Condon, Director, National Bureau of Standards.

Promulgation approved. 


\title{
WARM-AIR FURNACES EQUIPPED WITH VAPORIZING POT-TYPE OIL BURNERS
}

\section{COMMERCIAL STANDARD CS104-46}

\author{
(Second Edition)
}

\section{PURPOSE}

0.1 This standard is provided as a basis for certification of the quality and performance of warm-air furnaces equipped with vaporizing pot-type oil burners as covered herein, for the guidance of manufacturers, distributors, installers, contractors, and purchasers.

\section{SCOPE}

0.2 This standard applies to warm-air furnaces equipped with vaporizing pot-type oil burners and arranged with either gravity or forced-air circulation. It does not include floor furnaces. This standard is composed of the following sections:

Section

Page

0. Purpose, scope, definitions _...

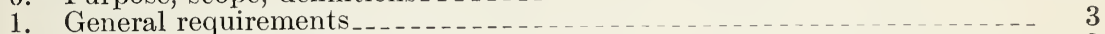

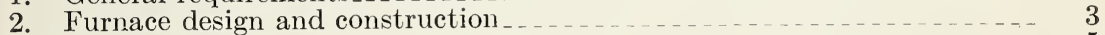

3. Performance................. 5

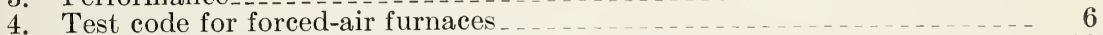

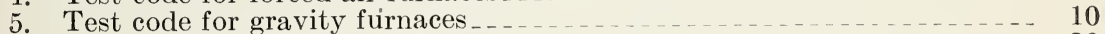

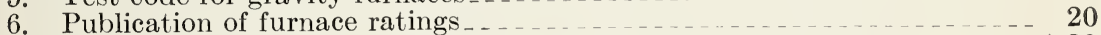

7. Informative labeling $\ldots \ldots \ldots \ldots$

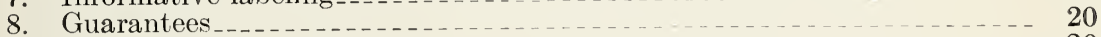

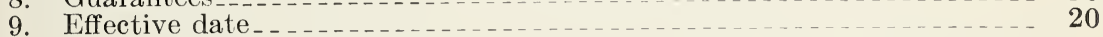

\section{DEFINITIONS}

0.31 Warm-air furnace.-A warm-air furnace is a device for enclosing and directly heating a given amount of air, having provisions for the attachment of pipes or ducts for circulating all of the enclosed heated air to desired locations. It may operate on either the gravity or the forced-air principle.

0.32 Gravity warm-air furnace.-A gravity furnace is defined as one which depends primarily upon the difference between the weight. of the heated air and the return cold air to produce circulation.

0.33 Forced-warm-air furnace. - A forced-air furnace is defined as one which depends upon a power-driven fan or blower to produce: circulation of the heated air. 
0.4 Vaporizing pot-type oil burner.-A device for the combustion of fuel oil, consisting of an oil-vaporizing bowl or other receptacle to which the liquid fuel may be fed in controllable quantities, the heat of combustion being used to vaporize the fuel, with provisions for admitting air and mixing it with the oil vapor in combustible proportions.

0.51 Standard air is air weighing $0.075 \mathrm{lb} / \mathrm{cu} \mathrm{ft}$. (This weight corresponds to dry air at $70^{\circ} \mathrm{F}$ or air with 50 -percent relative humidity at a dry-bulb temperature of $68^{\circ} \mathrm{F}$ when the barometric pressure is 29.92 in. mercury.) Specific heat is taken as 0.243.

0.52 Air delivery (cfm) is the quantity, in cubic feet of air, passing through the combination per minute, and corrected to standard conditions.

0.6 Static pressure loss in the connected duct system external to the casing is measured by means of two static-pressure tube connections located at points indicated on figure 1.

The net pressure loss in the duct system will be equal to suction-gage reading, plus discharge gage reading (irrespective of sign), minus the equivalent suction-velocity head. All readings are to be corrected to standard conditions.

0.71 Entering temperature $\left(T_{1}\right)$ is the average temperature of the air entering the furnace inlet, measured at the points indicated on figures 1 and 10, expressed in degrees Fahrenheit. If the thermometer (or thermocouple) as located is subject to radiation from heated surfaces, this temperature should be taken as the room temperature within $3 \mathrm{ft}$ of the inlet.

0.72 Final temperature $\left(T_{2}\right)$ is the average temperature of the air discharged from the furnace outlet, measured at the points indicated on figures 1 and 10, expressed in degrees Fahrenheit.

0.73 Flue-gas temperature $\left(T_{3}\right)$ is the average temperature of the flue gases measured at the point indicated on figure 2 , expressed in degrees Fahrenheit.

0.74 Room temperature $\left(T_{4}\right)$ is the average temperature of the air surrounding the furnace, taken with a shielded thermometer $3 \frac{1 / 2}{\mathrm{ft}}$ above the floor and not subject to drafts.

0.81 Oil input is the rate at which oil is supplied to the furnace, in pounds per hour.

0.82 Calorific value of the oil is the high heating value of the fuel used for the tests, expressed in Btu per pound, as specified in sections 4 and 5 , respectively.

0.83 Heat input is the total gross heating value of the oil supplied to the furnace, expressed in Btu per hour.

0.90 Bonnet.- The warm-air distribution chamber at the outlet of the furnace.

0.91 Bonnet capacity is the heat delivered at the bonnet of the furnace, expressed in Btu per hour. This capacity is to be used when the furnace is installed exterior to the space to be heated.

0.92 Bonnet efficiency is the percentage of heat input which is delivered at the bonnet of the furnace.

0.93 Gross output is the heat, expressed in Btu per hour, available for space heating, including the heat transfer through the casing, plenum chamber, and exposed stack. This output is to be used when the furnace is installed within the space to be heated. 
0.94 Stack loss is the percentage of the heat value of the fuel escaping, as indicated by the combustion efficiency chart.

0.95 Gross efficiency is the percentage of heat input which is available for gross output delivery.

0.96 Manufacturer.-For the purpose of this standard, the manufacturer shall be the company or organization which evidences its responsibility to the purchaser by (1) permanently affixing its name, address, and nationally registered trade-mark or trade name to the furnace, (2) printing its name, address, and nationally registered trade-mark or trade name on the instructions, and (3) by having its name and address listed in the Underwriters' Laboratories, Inc., List of Inspected Appliances.

\section{GENERAL REQUIREMENTS}

1.1 Safety.-The furnace and burner shall meet the safety requirements of the Underwriters' Laboratories, Inc., and the National Board of Fire Underwriters. Presence on the furnace of the label of Underwriters' Laboratories, Inc., shall be accepted as evidence of compliance with these safety requirements for the application for which the equipment is listed.

1.2 Durability. The design and construction of the furnace and burner shall be such as to ensure its durability in service as outlined in section 2 .

1.3 Dependability.-The furnace and burner shall be capable of functioning uniformly and reliably when installed and adjusted in accordance with the manufacturer's instructions.

1.4 Noise.- The furnace and burner shall be reasonably free from disturbing combustion and/or mechanical noises and shall cause no undue amount of radio interference.

1.5 Furnace testing and rating.-Each furnace model shall be tested and rated as outlined in sections 4 and 5 . The ratings shall be clearly set forth in the manufacturer's catalog or literature and on the furnace name plate as outlined in sections 6 and 7 .

1.6 Efficiency. The furnace shall be capable of meeting the minimum efficiency requirements outlined in section 3 .

1.7 Operating instructions.-Each furnace shall be accompanied by a complete set of instructions covering essential points with respect to selection of fuel, installation, operation, and upkeep.

\section{FURNACE DESIGN AND CONSTRUCTION}

2.1 The outer casing, or jacket, shall be constructed of steel or other suitable material and of such design that it is not readily damaged or dented in shipment or use.

2.2 Oil burners shall be of the vaporizing pot type, constructed of steel, not lighter than 20 gage (see par. 2.7 ), or other suitable material of equal resistance to heat, corrosion, and fuel leakage.

2.3 Combustion chambers, radiating drums and/or other surfaces exposed to the direct heat of the burner flame shall be constructed of sheet steel not lighter than 20 gage, or other suitable material. Combustion chambers shall be fitted with doors or equivalent means for permitting access to interior surfaces of the burner and other surfaces as required for lighting, cleaning, servicing, etc. 
2.4 Radiators or economizers, when used, shall be constructed of not lighter than 20-gage steel, or other suitable material, and the construction shall be such as to ensure strength, rigidity, and durability. The total area of the flue passages shall never be less than that of a 6-in.-diameter pipe.

2.5-The flue collar shall be constructed of cast iron, or of sheet steel of suitable thickness, but not less than 20 gage, and shall be rigidly attached at the flue outlet of the furnace. It shall afford convenient suitable means for attaching the flue pipe securely to the flue collar.

2.6 Finish.-Outside surfaces of furnace casings, grilles, and accessories shall be adequately protected against rust or corrosion and against damage during manufacture, test, shipment, and reasonable conditions of storage. The casing shall be protected by the use of baffles, inner liner, or insulating material to ensure durability of the finish.

2.7 Sheet-steel gages.-All sheet-steel gages specified in this standard shall be interpreted as indicated below:

\begin{tabular}{|l|l|}
\hline \hline $\begin{array}{c}\text { Manufacturers' stand- } \\
\text { ard practice gage } \\
\text { numbers }\end{array}$ & Thickness (in.) \\
\hline & \\
\hline 18 & 0.0478 plus or minus mill tolerance. \\
\hline 20359 plus or minus mill tolerance. & .0299 plus or minus mill tolerance. \\
22 & .0239 plus or minus mill tolerance. \\
26 & .0179 plus or minus mill tolerance. \\
\hline 28 & .0149 plus or minus mill tolerance. \\
\hline
\end{tabular}

\subsection{Furnace accessories and fittings.}

2.81 The means for oil control shall be of substantial construction of corrosion-resistant parts, with provisions for rigid attachment to the furnace, or it may be furnished integral with a constant-level valve. The control valve or other means for oil control shall be accessible for operation and servicing and shall have means for controlling the desired oil flow and restricting the maximum setting.

2.82 The constant-level valve shall be of the manual reset, float-andtrip type permitting air escapement, or otherwise be so constructed as to prevent excessive accumulations of oil in the valve. It shall have provisions for rigid mounting on the furnace and be supported independently of the piping. All parts shall be made of corrosionresistant material.

2.83 An automatic draft regulator, meeting the requirements of the Underwriter's' Laboratories, Inc., shall be furnished with each oil furnace. It may be furnished integral with the furnace, or with instructions for its installation.

2.84 Gaskets, where required for fuel-handling parts, shall be of soft copper, copper-asbestos, hard lead, or approved equivalent for screwed-joints, and of Underwriters' Laboratories, Inc., listed sheet packing or its equivalent for bolted joints.

2.85 Electric equipment.-All electric parts, including electric controls and electric motors, shall meet the safety requirements of the Underwriters' Laboratories, Inc., for such equipment. Burner and fan motors of one-eighth horsepower and over shall be of the generalpurpose type and commercially accepted as being free from objectionable radio interference. The maximum load on motor under con- 
ditions of maximum rating test shall not exceed its name-plate rating, except that general purpose motors with a service factor as defined by $\mathrm{NEMA}^{1}$ standards shall be considered as meeting the above requirement when provided with suitable overtemperature protection. Means shall be provided for the prevention of static accumulations.

2.86 Air filters when used must be so located that no point on the filter will reach a temperature in excess of $90^{\circ} \mathrm{F}$ above room temperature when the furnace is being operated at maximum output with the forced-air equipment either operating or not operating. Average velocity through filters shall not exceed $300 \mathrm{fpm}$. Filter area shall be based on nominal external dimensions.

\section{PERFORMANCE}

3.0 The furnace shall be capable of meeting the following minimum performance requirements, when tested as outlined in sections 4 and 5.

3.1 Lighting and warming up burner.-Adequate provision shall be made to insure ease of lighting, and to insure against extinguishment of the burner flame after lighting and before the burner has become thoroughly heated.

3.2 Operating of burner and controls.

3.21 Controls shall reliably perform the respective functions for which they are intended.

3.22 The burner shall be capable of functioning uniformly and reliably without excessive carbonization or other phenomena that would impair its safe and proper operation on the grades of fuel recommended by the manufacturer for use therein.

\subsection{Heating capacity.}

3.31 The furnace shall be capable of delivering heat as rated by the manufacturer when tested as outlined in sections 4 and 5 . The temperature of the metal of the heating surfaces shall not exceed $930^{\circ} \mathrm{F}$ above inlet air temperature under conditions of the rating test as specified in sections 4 and 5, unless constructed of heat-resisting material suitable for the temperature encountered.

3.4 Air delivery.

3.41 The blower in a forced-air furnace shall be capable of delivering the full rated output of the furnace with an air-temperature rise of $90^{\circ} \mathrm{F}$ (plus or minus $10^{\circ} \mathrm{F}$ ) when tested as outlined in section 4 against a static pressure in the connected duct system, external to the casing, as shown in section 4 .

\subsection{Operating efficiency.}

3.51 When tested at manufacturer's recommended draft and at full rated output as outlined in sections 4 and 5 , furnaces shall be capable of operating at the following efficiencies:

(a) 72-percent gross efficiency on forced-air furnaces equipped with natural- or mechanical-draft burners.

(b) 70-percent gross efficiency on gravity furnaces equipped with either natural- or mechanical-draft burners. 


\section{TEST CODE FOR FORCED-AIR FURNACES}

4.1 The Btu input, output, efficiency, and cfm air delivery shall be determined in accordance with the following method or its equivalent as approved by the standing committee:

4.2 Arrangement of testing apparatus for forced-air furnace.

4.21 The furnace and filter, if provided for in furnace construction, shall be installed in accordance with the manufacturer's instructions. The furnace shall be provided with inlet and outlet ducts, as shown in figure 1. Connections shall be provided for measuring the static pressure at the points at which the outlet duct is connected to the furnace, and thermometers or suitable means shall be used in the duct to obtain the average temperature of the inlet and outlet air. $\mathrm{Hu}$ midifiers, if provided, shall be in place but left dry. The furnace shall be connected to a source of draft. The instruments for weighing the fuel used, testing draft and static pressure, measuring stack temperature and temperatures of inlet and outlet air, sampling flue gas, and checking smoke shall be installed as shown in figures 1 to 6 , inclusive.

4.22 There shall be no check-draft damper between the furnace and the point where the flue-gas sample is taken or the flue-gas temperature measured; if one is incorporated in the furnace, it shall be thoroughly sealed during all tests.

4.23 Source of draft.- The draft may be produced by a chimney, or by a fan or other arrangement for providing induced draft.

4.24 Soot and dust.-The heating surfaces, furnace, flues, and chimney shall be clean and free from soot and dust at the beginning of the test.

4.3 Instruments and measuring apparatus.

4.31 Weighing scales for determining fuel consumption, draft gages, pressure gages, barometer, thermometers, pyrometer with ICHAM ${ }^{2}$ standard thermocouple for measuring stack temperature, ICHAM smoke meter and orsat gas analyzer of suitable accuracy shall be provided and installed as outlined in paragraph 4.21 above.

4.32 Weighing scales.-Scales accurate to $0.01 \mathrm{lb}$ shall be provided for weighing fuel oil.

4.33 Draft gages.-Measurements shall be made with gages reading to $0.01 \mathrm{in}$. of water. Gages shall be checked for zero reading at the beginning and the end of each test. A draft gage with an accuracy of plus or minus 0.0025 -in. water column shall be used.

4.34 Pressure gage.--An inclined draft gage shall be provided and arranged as shown in figure 1 to determine the pressure loss in the connected duct system external to the casing. Measurements shall be made with a gage reading to 0.01 in. of water. A draft gage with an accuracy of plus or minus $0.0025 \mathrm{in}$. shall be used. The static pressure connections shall consist of a 1/4-in-diam nipple soldered to the surface of the duct and centered over a hole 0.040 in. in diameter drilled through the sheet-metal duct. The inner surface of the duct shall be free from burrs and irregularities.

4.35 Fan measurements. - A wattmeter shall be placed in the electric circuit of the fan motor to measure the power consumption. A revolution counter, or other equal instrument, shall be provided to measure the speed of the fan.

\footnotetext{
${ }^{2}$ Institute of Cooking \& Heating Appliance Manufacturers.
} 
4.36 Temperature measurement.-Accurately calibrated instruments shall be provided for all temperature measurements. Mercury thermometers or thermocouples may be used, the latter being preferable.

4.37 Flue-gas analysis. - The flue-gas sample for analysis shall be taken as indicated in figures 2 and 3.

A three pipette orsat or equivalent gas analyzer shall be used.

4.4 Calorific value of fuel.

4.41 The API ${ }^{3}$ gravity of the fuel shall be determined with a hydrometer according to ASTM ${ }^{4}$ specifications and recorded on the test report.

4.42 The fuel used for furnace-rating tests shall be of the heaviest grade recommended by the manufacturer and shall be assumed to have a gross heating value as given in the following table.

Calorific values for fuel oil ${ }^{1}$

\begin{tabular}{|c|c|c|c|}
\hline \hline $\begin{array}{c}\text { Degrees } \\
\text { API at } \\
60^{\circ} \mathrm{F}\end{array}$ & $\begin{array}{c}\text { Density, } \\
\text { pounds per } \\
\text { gallon }\end{array}$ & $\begin{array}{c}\text { Btu per } \\
\text { pound }\end{array}$ & $\begin{array}{c}\text { Btu per } \\
\text { gallon }\end{array}$ \\
\cline { 1 - 2 } 28 & 7.396 & 19,350 & 143,100 \\
29 & 7.350 & 19,380 & 142,500 \\
30 & 7.305 & 19,420 & 141,800 \\
31 & 7.260 & 19,450 & 141,200 \\
32 & 7.215 & 19,490 & 140,600 \\
33 & 7.171 & 19,520 & 140,000 \\
34 & 7.128 & 19,560 & 139,400 \\
35 & 7.085 & 19,590 & 138,800 \\
36 & 7.043 & 19,620 & 138.200 \\
37 & 7.011 & 19,650 & 137,600 \\
38 & 6.960 & 19,680 & 137,000 \\
39 & 6.920 & 19,720 & 136,400 \\
40 & 6.879 & 19,750 & 135,800 \\
41 & 6.839 & 19,780 & 135,200 \\
42 & 6.799 & 19,810 & 134,700 \\
& & & \\
\hline
\end{tabular}

${ }_{1}^{1}$ The above figures are from National Bureau of Standards Miscellaneous Publication M97 (table 6).

4.43 Correction to standard API gravity at $60^{\circ} \mathrm{F}^{1-}$

\begin{tabular}{|c|c|c|c|c|c|c|c|c|c|c|c|c|c|c|c|}
\hline \multirow{2}{*}{$\begin{array}{l}\text { Ob- } \\
\text { served } \\
\text { temp } \\
\text { of oil }\end{array}$} & \multicolumn{15}{|c|}{ Observed gravity (degrees A PI) } \\
\hline & 28 & 29 & 30 & 31 & 32 & 33 & 34 & 35 & 36 & 37 & 38 & 39 & 40 & 41 & 42 \\
\hline${ }^{\circ} \mathrm{F}$ & & & & & & & & & & & & & & & \\
\hline 50 & $\begin{array}{l}28.7 \\
28.0\end{array}$ & 29.7 & $\begin{array}{l}30.7 \\
30.0\end{array}$ & 31.7 & 32.7 & 33.7 & 34.7 & 35. 7 & $\begin{array}{l}36.7 \\
36.0\end{array}$ & $\begin{array}{l}37.7 \\
37.0\end{array}$ & $\begin{array}{l}38.8 \\
38.0\end{array}$ & $\begin{array}{l}39.8 \\
39.0\end{array}$ & 40.8 & 41.8 & $\begin{array}{r}42.8 \\
42.0\end{array}$ \\
\hline 70 & 27.4 & 28.3 & 29.3 & 30.3 & 31.3 & $\begin{array}{l}32.0 \\
32.3\end{array}$ & 33.3 & 34.3 & 35.3 & 36.2 & $\begin{array}{l}37.2 \\
\text { 3. }\end{array}$ & 38.2 & 39.2 & 40.2 & 41. 2 \\
\hline & 26.7 & 27.7 & 28.7 & 29.6 & 30.6 & 31.6 & 32.6 & 33. 6 & 34.6 & 35.5 & 36.5 & 37.5 & 38.4 & 39.4 & 40.4 \\
\hline & 26.1 & 27.1 & 28.0 & 29.0 & 30.0 & 30.9 & 31.9 & $\begin{array}{l}32.9 \\
\end{array}$ & 33.8 & 34.8 & 35.8 & 36.7 & 37.7 & 38.7 & 39.6 \\
\hline 100 & 25.5 . & 26.5 & 27.4 & 28.4 & 29.3 & 30.3 & 31.3 & 32.2 & 33.2 & 34.1 & 35.1 & 36.1 & 37.0 & 37.9 & 38.9 \\
\hline
\end{tabular}

1 The above figures are from National Standard Petroleum Oil Table, NBS Circular C410 (March 4, 1936)

\subsection{Test conditions.}

4.51 The tests shall be run under the following specified conditions:

(a) The furnace shall be operated under rated test conditions until equilibrium conditions of air temperatures, fuel-flow rate, and flue-gas temperature have been established.

3 American Petroleum Institute.

4 American Society For Testing Materials.

$687192-46-2$ 
(b) The average draft during the test shall be that recommended by the manufacturer for high fire operation, but not to exceed 0.06 -in. water column for natural draft, not to exceed 0.04 in. for mechanical-draft burners, and not less than 0.02-in. water column for either. The maximum fluctuation in draft during the test shall not exceed plus or minus 0.005 -in. water column.

(c) The fuel-feed rate shall be such that the temperature of the outlet air exceeds the temperature of the inlet air by $90^{\circ} \mathrm{F}$ (plus or minus $10^{\circ} \mathrm{F}$ ) but not above the rate at which the amount of smoke in the flue gases. reaches the maximum allowable by the ICHAM smoke test (10 percent reading after a 20-min exposure).

(d) The observed flue-gas temperature at maximum-output rating shall not be less than $300^{\circ} \mathrm{F}$ nor more than $880^{\circ} \mathrm{F}$ above laboratory temperature for natural-draft burners, nor more than $780^{\circ} \mathrm{F}$ above laboratory temperature for mechanicaldraft burners, and the percentage of $\mathrm{CO}_{2}$ in the stack gases shall be not less than 10 .

(e) The above tests shall be conducted at the maximum and minimum ratings specified by the manufacturer.

4.52 Unburned fuel gases shall not occur in the flue products in sufficient quantities to exceed the following:

4.521 To be measurable by recognized methods of gas analysis as unburned fuel gas or vapors in excess of 0.2 percent by volume, or

4.522 To result in failure of the observed $\mathrm{CO}_{2}$ and $\mathrm{O}_{2}$ values to check at the ultimate by more than 0.5 percent of $\mathrm{O}_{2}$ on the check chart, figure 7 .

4.53 Furnaces shall be tested with a total external static pressure ${ }^{5}$ varying according to the rated $\mathrm{cfm}$ output reduced to standard density in accordance with the following table:

\begin{tabular}{|c|c|}
\hline \hline Cfm & $\begin{array}{c}\text { External } \\
\text { static } \\
\text { pressure }\end{array}$ \\
\hline & in. \\
\hline Oto 800 & 0.15 \\
Over 800 to 1, 600 & .20 \\
Over 1,600 to 3,000 & .25 \\
Over 3,000 to 6,000 & .30 \\
\hline
\end{tabular}

4.6 Observations during tests.-After equilibrium conditions have been established, the actual rating test shall be started and continued for at least 1 hour.

4.61 The observations shall be made and recorded at the start of the test and at three approximately equal intervals throughout the test.

4.62 The absence of visible red spots on the combustion chamber will be accepted as evidence of compliance with the temperature requirements of paragraph 3.31 .

4.7 Corrections for altitude.

4.71 The appropriate correction factor from the following table may be used for converting the fuel-oil-input rate at the smoke point

5 This is identical with the pressure loss in the eonnected duct system external to the easing, as defined in par. 0.6 . 
at higher altitudes to the corresponding fuel-input rate at sea level. (In no case, however, shall the corrected fuel-input rate used for furnace rating purposes exceed the maximum fuel-flow rate obtainable at high fire valve setting with recommended fuels.)
4.72
Table of altitude correction factors.-

\begin{tabular}{|c|c|c|c|c|c|}
\hline $\begin{array}{l}\text { Approximate } \\
\text { altitude a }\end{array}$ & $\begin{array}{c}\text { Barometric } \\
\text { pressure }\end{array}$ & $\begin{array}{l}\text { Correction } \\
\text { factor }\end{array}$ & $\begin{array}{l}\text { Approximate } \\
\text { altitude : }\end{array}$ & $\begin{array}{l}\text { Barometric } \\
\text { pressure }\end{array}$ & $\begin{array}{l}\text { Correction } \\
\text { factor }\end{array}$ \\
\hline $\begin{array}{c}f t \\
0,1,000 \\
1,500 \\
2,000 \\
2,500 \\
3,000 \\
3,500\end{array}$ & $\begin{array}{r}\text { in. mercury } \\
30.0 \\
29.5 \\
29.0 \\
28.5 \\
28.0 \\
27.5 \\
27.0 \\
26.5\end{array}$ & $\begin{array}{l}1.00 \\
1.02 \\
1.04 \\
1.06 \\
1.08 \\
1.10 \\
1.12 \\
1.14\end{array}$ & $\begin{array}{c}f t \\
4,000 \ldots \\
4,500 \\
5,000 \\
5,500 \\
6,000 \\
6,500 \\
7,000 \ldots\end{array}$ & $\begin{array}{r}\text { in. mercury } \\
26.0 \\
25.5 \\
25.0 \\
24.5 \\
24.0 \\
23.5 \\
23.0\end{array}$ & $\begin{array}{l}1.16 \\
1.18 \\
1.20 \\
1.22 \\
1.24 \\
1.26 \\
1.28\end{array}$ \\
\hline
\end{tabular}

a The effective furnace-output rating for regions higher than sea level may be estimated by dividing the rated hourly heat output at sea level by the conversion factor corresponding to the higher altitude indicated in the above table. If provisions are made for assuring correct air supply for high-altitude work in accordance with the above table, this correction in output is not required. Such units as are intended for highaltitude work shall be plainly marked adjacent to the manufacturer's rating name plate with the altitude range for which they are designed.

\subsection{Determination of bonnet capacities.}

4.81 Until such time as the industry adopts a uniform method of measuring bonnet output, bonnet capacities may be determined either by actual test, using the American Society of Refrigerating Engineers Standard Methods of Rating and Testing Self-Contained Air Conditioning Units for Comfort Cooling, ASRE Circular No. 16, or a windtunnel method hereinafter approved by the manufacturer representatives on the standing committee, or may be approximated by deducting 5 percent from the gross heat output. When bonnet capacities are specified, the manufacturer shall clearly indicate in his literature the method used.

4.82 Rated cfm output.-The cubic-feet-per-minute air delivery under standard conditions may be determined by actual test as specified under paragraph 4.81 or from the following formula, using the setup shown in figure 1.

simplified

$$
\mathrm{cfm}=\frac{0.95 \times \mathrm{Btu}}{0.243 \times 60 \times 0.075 \times\left(T_{2}-T_{1}\right)}
$$

$$
\operatorname{cfm}=\frac{0.869 \times \mathrm{Btu}}{T_{2}-T_{1}}
$$

Btu $=$ Gross Btu output per hour.

$\mathrm{cfm}=$ Cubic feet per minute.

$0.243=$ Specific heat of air.

$60=$ Minutes per hour.

$0.075=$ Weight of $1 \mathrm{cu} \mathrm{ft}$ of air at $70^{\circ} \mathrm{F}$ at $29.92 \mathrm{in}$. barometer.

$T_{1}=$ Average inlet-air temperature in ${ }^{\circ} \mathrm{F}$.

$T_{2}=$ Average outlet-air temperature in ${ }^{\circ} \mathrm{F}$.

4.83 The Btu input shall be determined by multiplying together the pounds of fuel used per hour and the Btu per pound as obtained from paragraph 4.42, using the gravity corrections specified under paragraph 4.43. 


\section{TEST CODE FOR GRAVITY FURNACES}

5.1 The Btu input, output, efficiency, and cfm air delivery shall be determined in accordance with the following method:

5.2 Arrangement of testing apparatus for gravity furnace.-

5.21 Gravity furnace shall be equipped with a bonnet and with leader pipe collars of conventional type to fit 8-in., 10-in., or 12-in. leader pipe, as selected by the manufacturer. The combined crosssectional area of the leader pipe in square inches shall not exceed

$$
\frac{0.70 \times \text { Btu input }}{111}
$$

Note.-(This formula is based on using an assumed 70-percent efficiency and the figure of 111 is used as the number of Btu carried by $1 \mathrm{sq}$ in. of pipe area.) The combined area of the leader pipe openings shall be as uniformly distributed around the bonnet as possible. If provisions are made for such installation in the field, there may be two return air-duct openings having the same total area as the leader pipes used. The furnace manufacturer shall provide suitable return-air pipes the full size of these return openings and $8 \mathrm{in}$. long, as shown on figure 10. The furnace shall be set up and provided with test leader pipes, as shown on figure 10 . It shall be connected to a source of draft and the instruments for measuring fuel used, testing draft, measuring stack temperature and temperatures of incoming and outgoing air, sampling flue gas, and checking smoke shall be located as shown on figures 1 to 6 , inclusive.

Furnaces equipped with a single floor register directly attached to the plenum providing the principal means for discharge of the heated air shall be tested with the register in place and be set at an elevation of $7 \mathrm{ft} 6 \mathrm{in}$. above the base of the furnace. Auxiliary leader-pipe openings, if used, shall be fitted with test leader pipes, as shown on figure 10 .

5.22 The provisions of paragraphs $4.22,4.23$, and 4.24 shall apply to the testing of gravity furnaces.

5.3 Instruments and measuring apparatus.

5.31 The instruments and measuring apparatus used shall be the same as specified in paragraphs 4.31 to 4.37 , inclusive, omitting paragraphs 4.34 and 4.35 .

5.4 Calorific value of fuel.

5.41 The calorific value of the fuel shall be determined as specified in paragraphs $4.41,4.42$, and 4.43 .

5.5 Test conditions.

5.51 The tests shall be run under the following specified conditions:

(a) The furnace shall be operated under rated test conditions until equilibrium conditions of air temperatures, fuel flow rate, and flue-gas temperature have been established.

(b) The average draft during the test shall be that recommended by the manufacturer for high fire operation, but not to exceed 0.06 -in. water column and not less than 0.02 -in. water column. The maximum fluctuation in draft during the test shall not exceed plus or minus 0.005 -in. water column.

(c) The fuel feed rate shall be the maximum recommended by the manufacturer but

(1) not above that rate at which the temperature of the air at any outlet exceeds the temperature of the inlet air by $160^{\circ} \mathrm{F}$,

(2) not above the rate at which the amount of smoke in the flue gases reached the maximum allowable by ICHAM smoke test (10-percent reading after 20-min exposure). 
(d) The temperature of the air at any warm air outlet shall not vary more than $30^{\circ} \mathrm{F}$ from the average of the discharge temperature observed at all of the warm-air outlets.

(e) The observed flue-gas temperature at maximum-output rating shall be not less than $300^{\circ} \mathrm{F}$ nor more than $920^{\circ} \mathrm{F}$ above laboratory temperature, and the percentage of $\mathrm{CO}_{2}$ in the stack gases shall be not less than 10 .

5.52 The provisions of paragraphs $4.52,4.521$, and 4.522 shall apply to this test.

5.6 Observations during test.-After equilibrium conditions have been established, the actual rating test shall be started and continued for at least 1 hour.

5.61 The observations shall be made and recorded at the start of the test and at three approximately equal intervals throughout the test. The form of data sheet shown on page 12 is to be used for recording the test data.

5.7 Corrections for altitude.

5.71 The correction factors shall be the same as specified in paragraphs 4.71 and 4.72 . 
STANDARD OIL-FURNACE RATING TEST FOR OBTAINING GROSS OUTPUT

Data and Report Sheet

Manufacturer's Test No.

Oil furnace.

Fuel used for test

Make

Model

Type or No. Number and size of burners

Date of test

Brand

API gravity at $60^{\circ} \mathrm{F}$

Tested by

API gravity at 60 5

1. Draft

(in. water)

2. Room temperature $T_{4}$

3. Smoke-meter readings

4. Fuel-temperature readings

5. Time intervals used for fuel readings

6. Fuel-input readings (specify units)

7. Fuel-oil input rate (lb/hr, avg)

8. Barometric pressure (in. mercury)

9. Factor to correct fuel input to sea level (par. 4.7)

10. Fuel-oil input (corrected to sea level) (lb/hr, avg)

11. Gross heating value of oil 1

(Btu/lb)

12. Gross heat input (corrected to sea level) (Btu/hr)

13. Flue-gas temperature

$\left({ }^{\circ} \mathrm{F}\right)$

14. Flue-gas temperature rise above room temperature.................................

15. $\mathrm{CO}_{2}$ in dry flue gas

16. $\mathrm{O}_{2}$ in dry flue gas

17. Unburned gases expressed as $\mathrm{CO}$

18. Gross efficiency for complete combustion from chart, figure 8 or 9 equal intervals $20 \mathrm{Avg}$ minutes apart

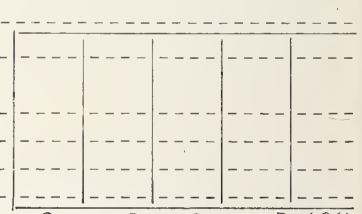

19. Percentage heat losses due to incomplete combustion (from formula) figure 7 $(\%)$

20. Gross furnace efficiency equals (item 18 minus item 19)

21. Gross Btu output equals (item 12 times item 20)

22. Outlet-air temperature, $t_{2}$ :

No. 1 thermometer or thermocouple

No. 2 thermometer or thermocouple

No. 3 thermometer or thermocouple

No. 4 thermometer or thermocouple

$T_{2}$ average.

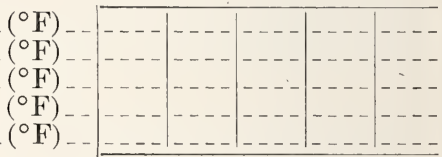

23. Inlet-air temperature, $t_{1}$ :

No. 1 thermometer or thermocouple

No. 2 thermometer or thermocouple

$T_{1}$ average

24. Average temperature rise equals (item 22 minus item 23)

25. Static pressure at bonnet outlet ${ }^{2}$

(in.)

26. Rated cfm output

27. Blower speed ${ }^{2}(\mathrm{rpm})$

28. Electrical input to blower motor ${ }^{2} \ldots \ldots \ldots$ volts

29. Commercial Standard grade of fuel used

30. Observed API gravity of fuel

31. API gravity of fuel corrected to $60^{\circ} \mathrm{F}$

We hereby certify that the above data are true and accurate copies of that obtained when the above heater was tested in accordance with sections 4 and 5 of Commercial Standard for Warm Air Furnaces Equipped With Vaporizing Pot-type Oil Burners, CS104-46.

For

Address

$\mathrm{By}$

\section{Date}

${ }^{1}$ For calorific value of fuel from table under 4.42, select closest value for A PI gravity as obtained for item 31. 2 Not required for gravity furnaces. 


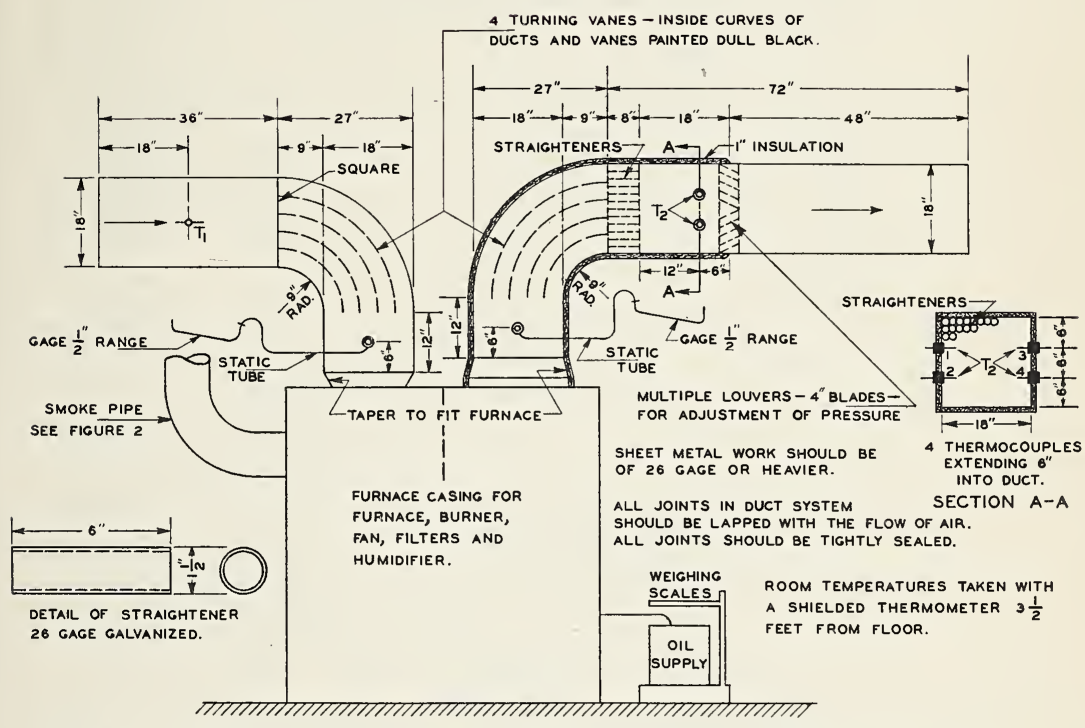

FIGURE 1.-Schematic diagram showing arrangement of apparatus for testing fanfurnace combination units. 

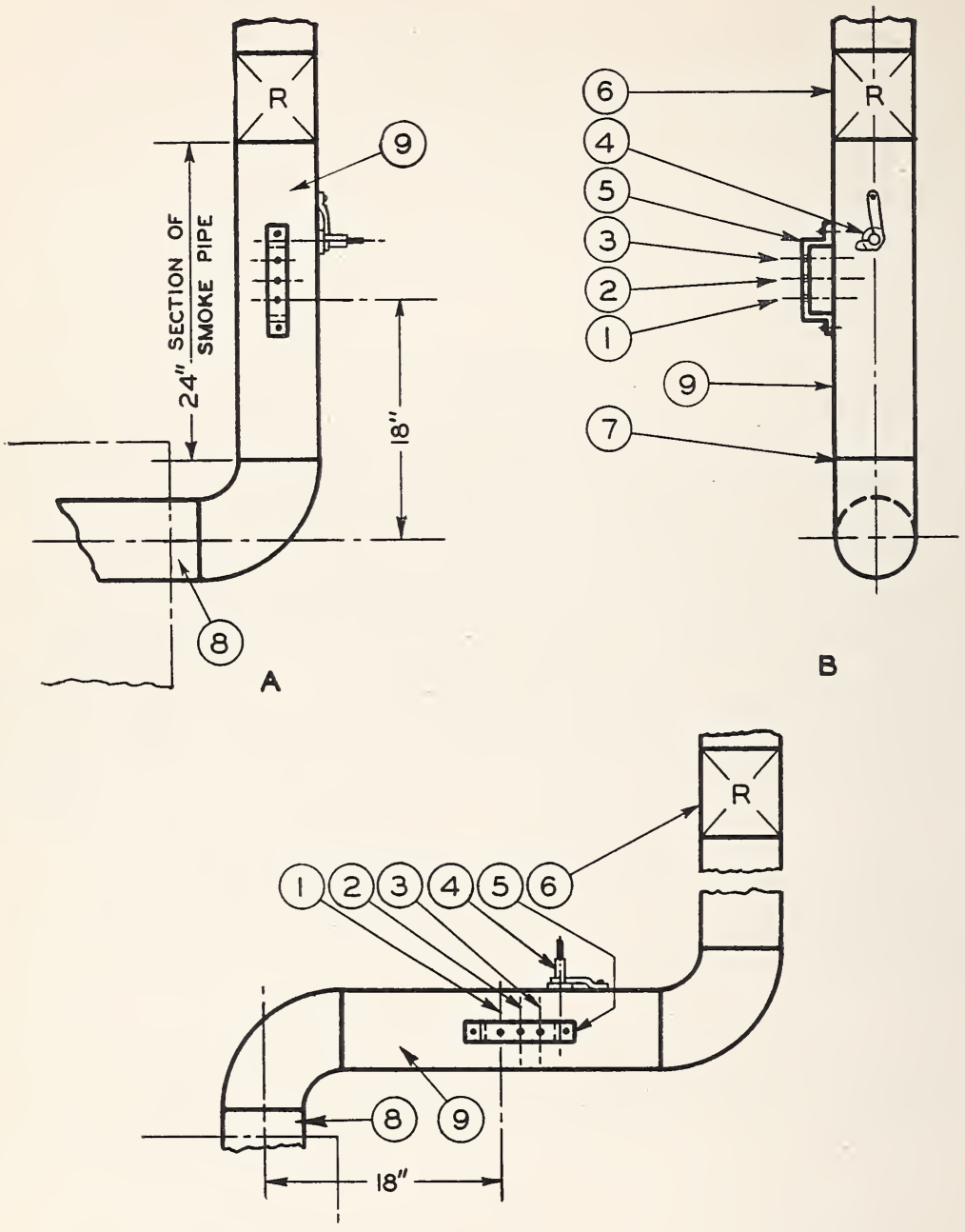

C

Figure 2.-Furnace flue connections.

1. Center line of thermocouple, see figures 3 and 4.

2. Gas-sampling tube, see figure 3 .

3 . Draft tube, see figure 3.

4. 8-mm clear-glass rod and holder, see figure 5 .

5. Support bracket, see figure 3 .

6. Draft regulator

7. Seal all openings in stove pipe below gas-sampling tube.

8. Flue collar.

9. Section of smoke pipe, same nominal diameter as furnace flue collar. 


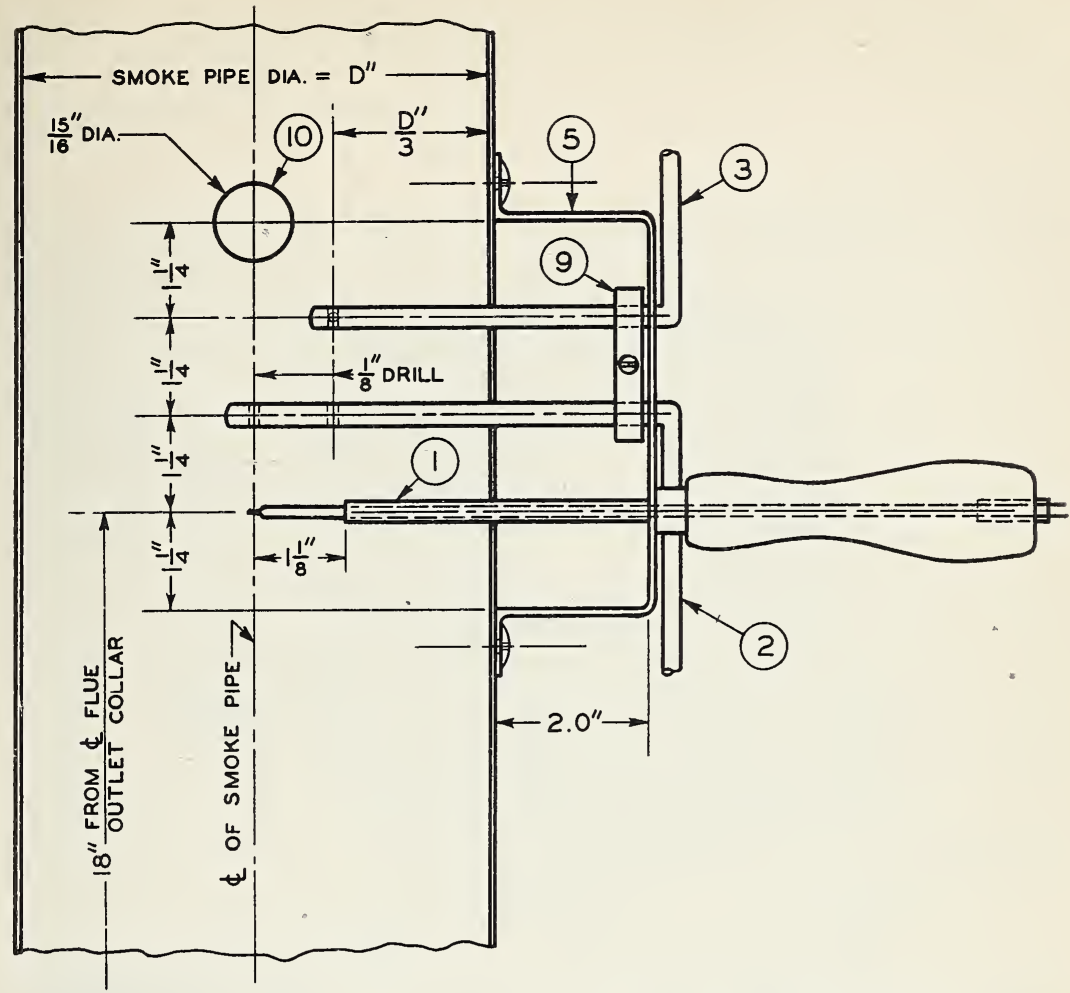

FIGURE 3.-Gas-sampling and draft tubes, thermocouple and support bracket assembly.

1. Thermocouple, see figure 4.

MATERIALS

2 and 3 . Gas-sampling and draft tubes (1/4- by approx. 0.032 -inch wall, yellow brass or steel).

5 and 9 . Support bracket and tube clamp (1/2-by 0.093 -inch half-hard flat steel wire).

10. Hole in smoke pipe for glass rod.
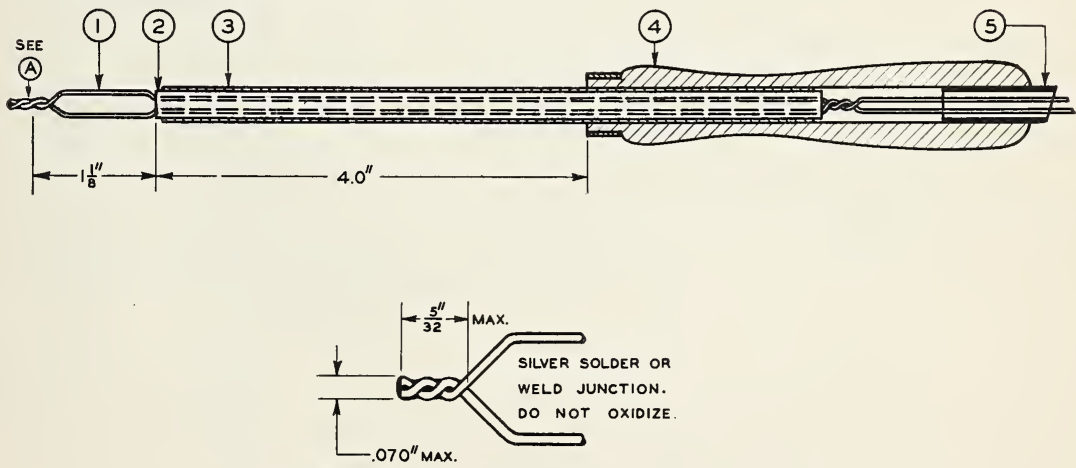

(A) DETAIL OF HOT JUNCTION

FIGURE 4.-Standard thermocouple for flue-gas temperature measurement.

1. $10^{\prime}-$ No. $20 \mathrm{~B} \& \mathrm{~S}$ gage iron-constantan, asbestos, or woven glass-covered thermocouple wires extending from hot junction to potentiometer or reference junction.

2. 1-Leeds \& Northrup standard 714B, or equal, 1/4 inch O. D.-2-hole porcelain insulator cut 6.0 in. long and ends beveled on two sides.

3. $1-5 / 16$-inch $\mathrm{O}$. D. by 0.032 -inch wall half-hard yellow-brass tubing cut $57 \%$ inches long. Ream. if necessary, to fit over insulator; then crimp ends over beveled ends of insulator.

4. 1-Small wooden handle.

5. 1-Piece of rubber tubing, $5 / 16$ by $3 / 32$ by 2 inches long. 


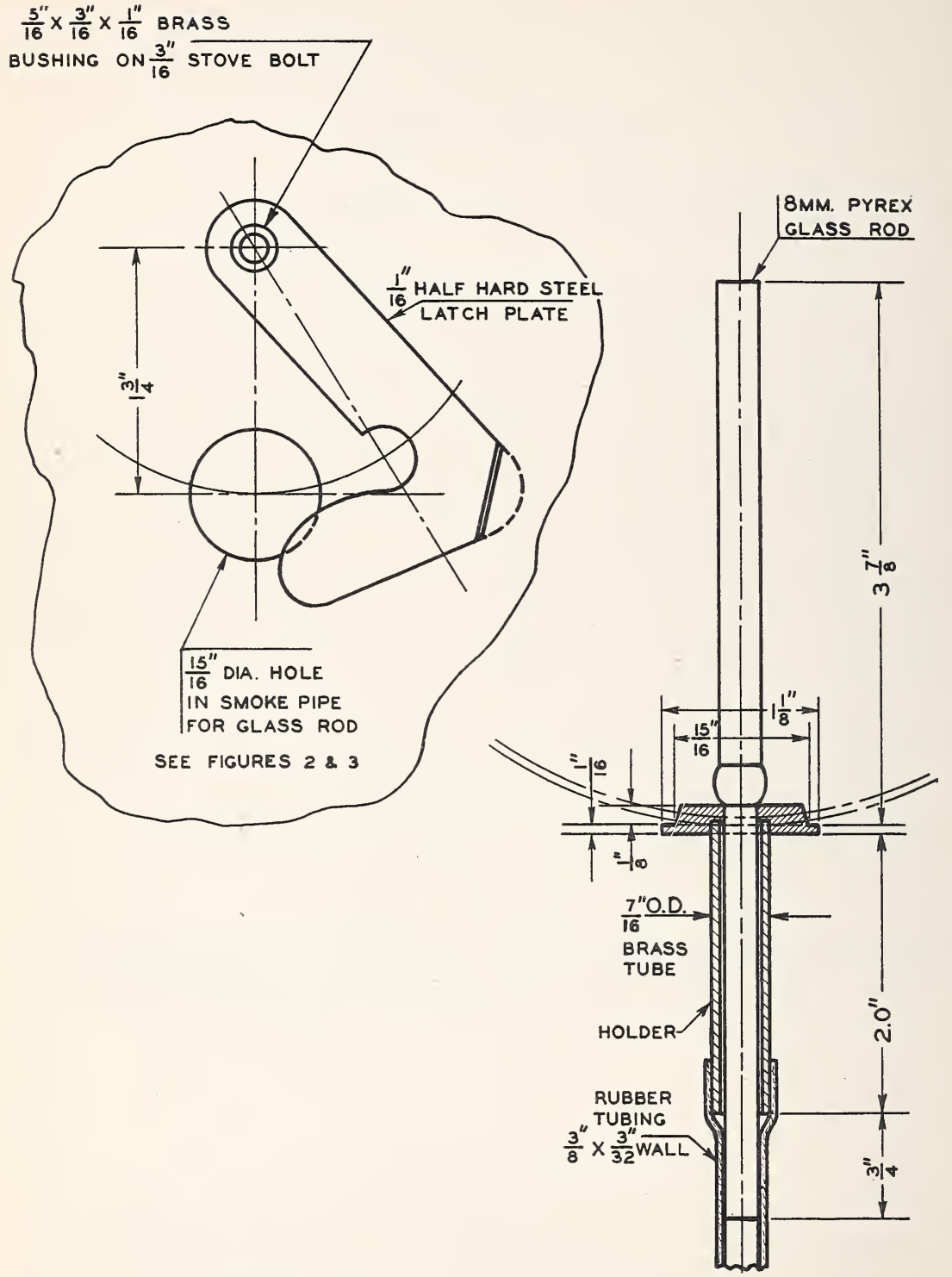

Figure 5.-Glass rod, rod holder, and latch plate.

Scale: Full size. 


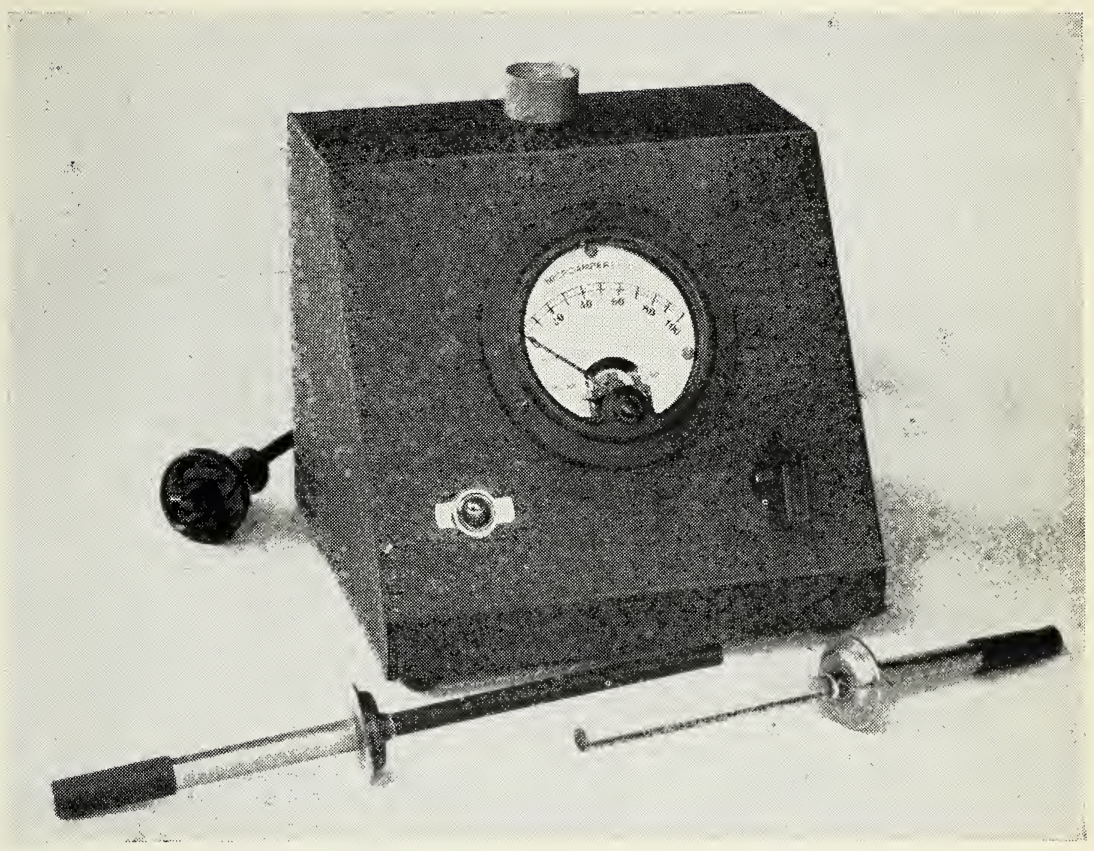

Figure 6.-Institute of Cooking \& Heating Appliance Manufacturers smoke meter.

Principle of Operation.-The smoke meter shown above is better described as a photoelectric soot-density comparator. Its operation and use are based on the principles that:

1. A Pyrex-glass rod placed across a stream of flue gas containing oil smoke will collect a deposit of soot on the surface of the rod.

2. Under specified exposure conditions, the amount or depth of soot deposit on the glass rod will be a function of the smoke density, or the proportion of smoke in the flue products.

3. The depth or amount of this smoke deposit can be measured or evaluated in terms of the extent to which it will interfere with the passage of a beam of light through the glass rod onto a photoelectric cell.

Description.- The meter consists of means for supporting a glass or metal rod and means for passing a beam of light through the glass rod onto a photoelectric cell connected to an electric meter. A constantvoltage transformer should be used if the line voltage fluctuates objectionably. The over-all size of the meter is approximately $51 / 2$ by $51 / 2$ by $6 \frac{1}{2}$ inches. Weight approximately 4 pounds without transformer.

Operation.-The meter is adjusted for a "zero" reading with a dull-black, opaque rod and for a 100 reading with a clean glass rod. The glass rod is then exposed to the smoke in the flue pipe and placed in the meter to give a reduced meter reading (percentage of light transmitted).

For further information regarding the ICHAM smoke meter write to the Institute of Cooking \& Heating Appliance Manufacturers, Shoreham Hotel, Washington, D. C. 



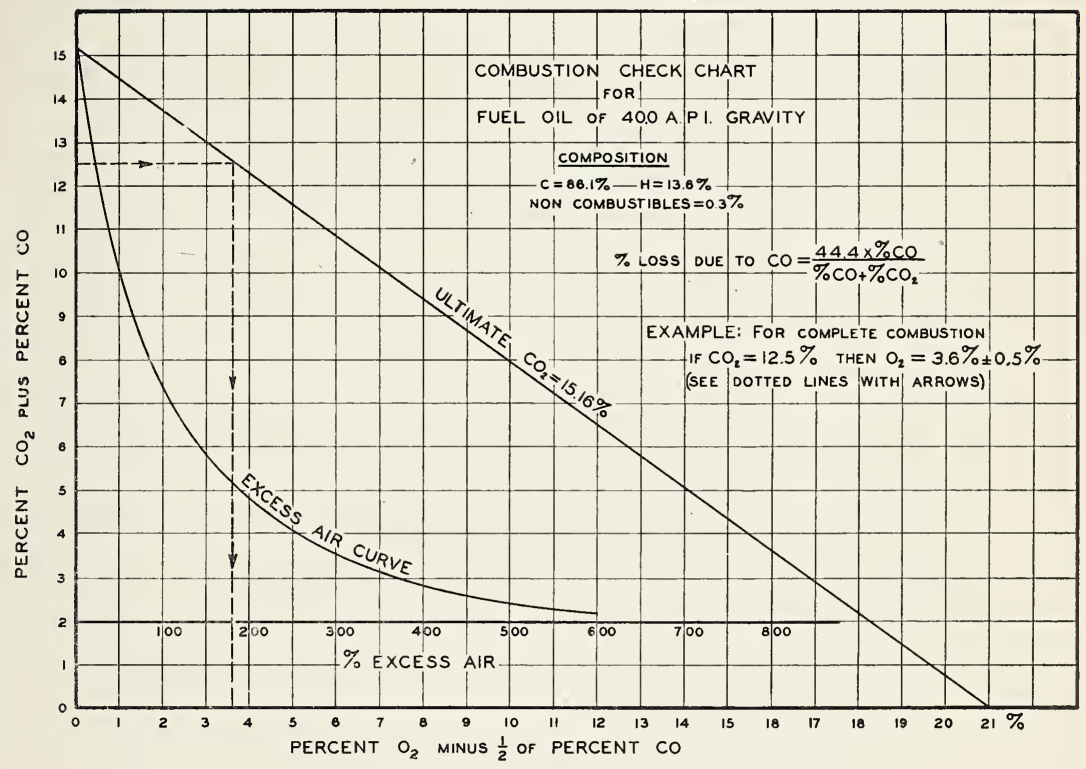

Figure 7.-Combustion check chart. 


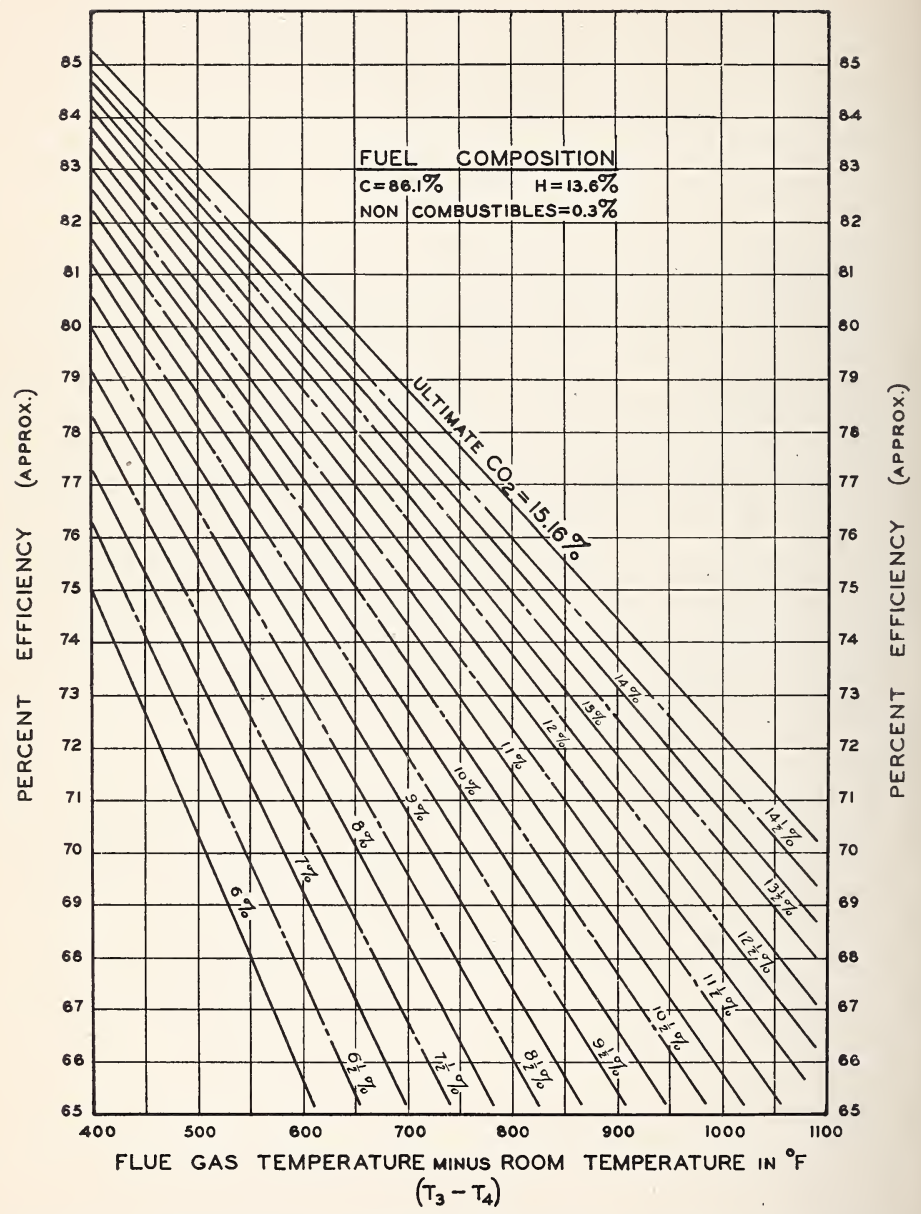

FIGURE 8.-Enlarged efficiency chart for warm-air furnaces equipped with vaporizing pot-type burners. 


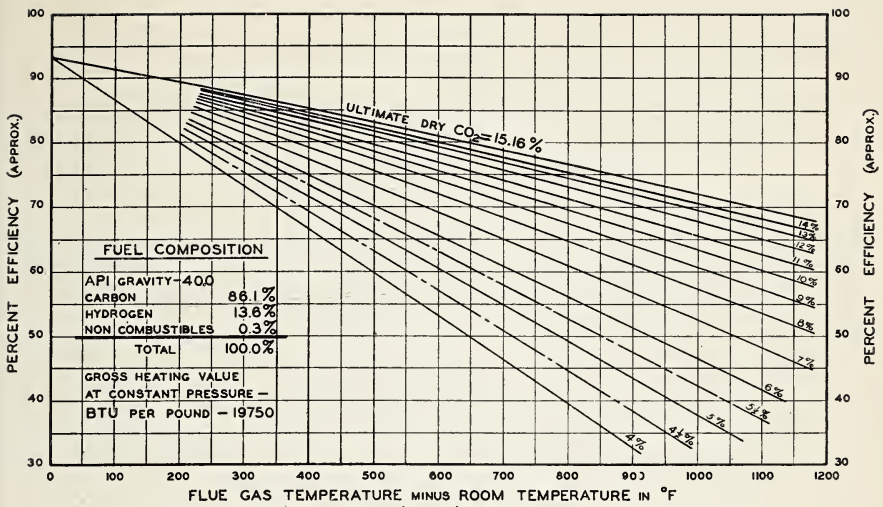

$$
\left(T_{3}-T_{4}\right)
$$

FIGURE 9.-Efficiency chart for warm-air furnaces equipped with vaporing pottype burners.

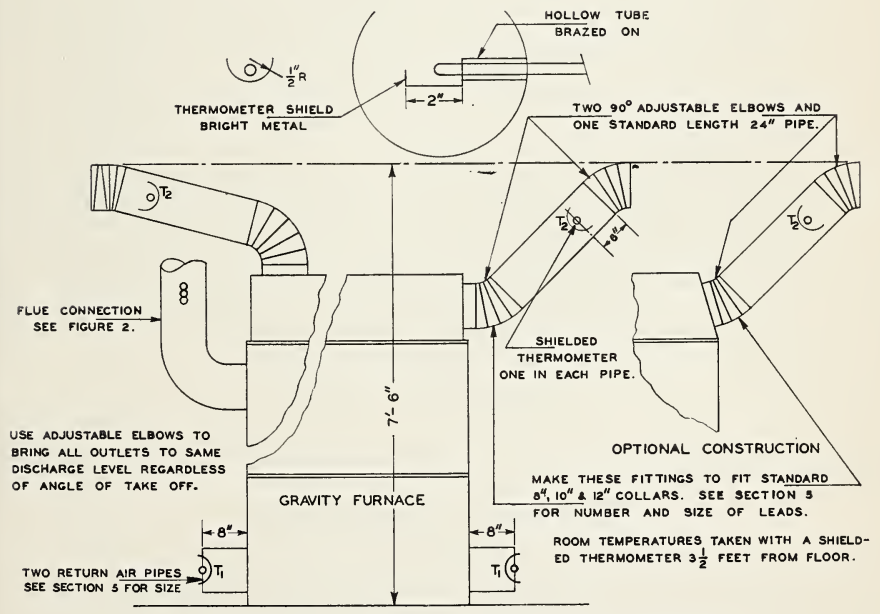

FigURE 10.-Gravity furnace-testing arrangement 


\section{PUBLICATION OF FURNACE RATINGS}

6.1 All published furnace ratings shall be determined as outlined in section 4 or 5 and shall be expressed thus:

Gross output_.......... Btu/hr at_..... draft with CS _........oil, and/or

Bonnet capacity _..._._._. Btu/hr at _...... draft with CS

Rated ef moutput-a- static pressure.

\section{INFORMATIVE LABELING}

7.1 The following data shall be permanently affixed to each furnace as evidence of compliance with the provisions of this standard. If rated for high altitude, see note under paragraph 4.72 .

Model No. - _..... CS No. CS104-46.

Bonnet capacity _... Btu/hr _...........

Gross output _..... Btu/hr

Tested at _... draft, using $\mathrm{CS}$ No.

Manufacturer's name and address graph 1.1 .

\section{GUARANTEES}

8.1 The following uniform guarantee or warranty shall accompany each furnace or be published in the manufacturer's printed literature or both:

warrants all oil-burning furnaces manufactured by it and bearing Commercial Standard CS104-46 to be free from defects in material and workmanship. If any part of the equipment herein described and sold by the company proves to be defective in workmanship or material, and if such part is within 12 months from date of shipment from the company's factory returned to such factory, transportation charges prepaid, and if the same is found by the company to be defective in workmanship or material, it will be replaced or repaired, free of charges, f. o. b. factory.

The company assumes no liability for consequential damages of any kind, and the purchaser by acceptance of this equipment will assume all liability for the consequences of its use or misuse by the purchaser, his employee, or others. A defect, in the meaning of this warranty, in any part of said equipment shall not, when such part is capable of being renewed, repaired, or replaced, operate to condemn such equipment. This warranty is expressly in lieu of all other warranties, guarantees, obligations, or liabilities, expressed or implied, by the company or its representatives.

\section{EFFECTIVE DATE}

9.1 The standard is effective for new production from March 15, 1946.

\section{STANDING COMMITTEE}

10.1 The following comprise the membership of the standing committee that is to review, prior to circulation for acceptance, proposed revisions to keep the standard abreast of progress. Each organization nominated its own representative. Comment and questions concerning the standard and suggestions for revision may be addressed to any member of the committee or to the Division of Trade Standards, 
National Bureau of Standards, which acts as secretary for the committee:

D. F. Jones (chairman), Duo-Therm Division, Motor Wheel Corporation Lansing 3, Mich.

A. T. Atwill, Quaker Manufacturing Co., 223 West Erie St., Chicago 10, Ill.

A. B. Newton, Airtemp Division, Chrysler Corporation, Dayton 1, Ohio.

Stanley Perry, Oil Devices, 341 East Ohio St., Chicago 11, Ill.

Marc Resek, Perfection Stove Co., 7609 Platt Avenue, Cleveland, Ohio.

George Schueder, Evans Products Corporation, Fullerton at Greenfield, Detroit 17 , Mich.

Ira G. Watson, Marshall-Wells Co., Duluth 1, Minn.

Gerald C. MacDonald, Montgomery Ward, 618 W. Chicago Ave., Chicago 7, IIl.

J. W. Essock, Department 642, Sears, Roebuck \& Co., 925 S. Homan Avenue, Chicago 7, Ill.

E. L. PUgh, Southern Wholesalers, Inc., 712 Volunteer Bldg., Atlanta 3, Ga.

H. C. Littre, H. C. Little Burner Co., Inc., San Rafael, Calif. (Representing Pacific Oil Burner Association.)

Thomas Hall Locraft, 1413 H St., N. W., Washington, D. C. (Representing American Institute of Architects.)

R. K. Thulman, Mechanical Equipment Section, Federal Housing Administration, 1001 Vermont Avenue, N. W., Washington 25, D. C.

Millard W. Merrill, United States Metals Refining Co., 400 Middlesex Avenue, Carteret, N. J. (Representing National Assn. of Purchasing Agents.)

Peter J. Furlong, Public Buildings Administration, Federal Works Agency, Washington $25, \mathrm{D}$. C.

Felix A. Peck ham, Corps of Engineers, War Department, Tempo Bldg. "H", 23d and C Sts., N. W., Washington 25, D. C.

S. Konzo, Department of Mechanical Engineering, University of Illinois, Urbana, Ill.

W. T. Miller, School of Mechanical Engineering, Purdue University, Lafayette, Ind.

J. H. Witte, Underwriters' Laboratories, Inc., 207 E. Ohio Street, Chicago 11, Ill.

Richard S. Dill, National Bureau of Standards, Washington 25, D. C.

\section{HISTORY OF PROJECT}

11.1 On July 14, 1941, an informal meeting of leading manufacturers recorded their desire to establish a test code for warm-air furnaces equipped with vaporizing pot-type oil burners. After a series of meetings for the preparation of a proposed standard, four representative manufacturers on March 18, 1942, requested the cooperation of the National Bureau of Standards in the establishment of a commercial standard and suggested that the draft as revised on Feb ruary 12,1942 , be used as a basis for further discussion.

12.1 The proposed standard was adjusted and tentatively adopted by a conference of manufacturers on April 17, 1942, in Chicago, Ill., held under the auspices of the National Bureau of Standards. Incomplete parts were supplied by the Technical Committee on June 11, 1942, and a second conference in Chicago on June 24, 1942, reviewed, revised, and adopted a later draft, which, on authority of the conference, was circulated widely for written comment.

13.1 Following suitable adjustment in line with the composite written comment, the revised draft was circulated on September 28, 1942 , to the entire trade for written acceptance, as it appeared from the comment that a general conference was unnecessary, particularly in view of the wartime emergency. Upon receipt of acceptances in writing from a preponderant majority, announcement was issued on 
December 9, 1942, that the standard would become effective for new production from January 1, 1943.

14.1 Subsequently, suggestions for revisions were received from various interested sources and submitted to the Standing Committee. The revisions as approved by that committee were incorporated in a revised draft which was circulated under date of September 19, 1945, to the trade for written acceptance. Written acceptances estimated to represent a satisfactory majority were obtained, and on February 19, 1946 the establishment of the revised standard was announced. 


\section{ACCEPTANCE OF COMMERCIAL STANDARD}

If acceptance has not previously been filed, this sheet properly filled in, signed, and returned will provide for the recording of your organization as an acceptor of this commercial standard.

Division of Trade Standards,

Date

National Bureau of Standards,

Washington 25, D. C.

Gentlemen:

We believe that the Commercial Standard CS104-46 constitutes a useful standard of practice, and we individually plan to utilize it as far as practicable in the

$\begin{array}{llll}\text { Production }^{1} & \text { Distribution }^{1} & \text { Purchase }{ }^{1} & \text { Testing } \\ & { }^{1}\end{array}$

of warm-air furnaces equipped with vaporizing pot-type oil burners. We reserve the right to depart from it as we deem advisable.

We understand, of course, that only those articles which actually comply with the standard in all respects can be identified or labeled as conforming thereto.

Signature of authorized officer

(In ink)

(Kinaly typewrite or print the following lines)

Name and title of above officer

Organization

(Fill in exactly as it should be listed)

Street address

City, zone, and State

1 Underscore which one. Please see that separate acceptances are filed for all subsidiary companies and affiliates which shoula be listed separately as acceptors. In the case of related interests, trade papers, etc., desiring to record their general support, the words "General Support" should be added after the signature. 


\section{TO THE ACCEPTOR}

The following statements answer the usual questions arising in connection with the acceptance and its significance:

1. Enforcement.-Commercial standards are commodity specifications voluntarily established by mutual consent of those concerned. They present a common basis of understanding between the producer, distributor, and consumer and should not be confused with any plan of governmental regulation or control. The United States Department of Commerce has no regulatory power in the enforcement of their provisions, but since they represent the wil] of the interested groups as a whole, their provisions through usage soon become established as trade customs, and are made effective through incorporation into sales contracts by means of labels, invoices and the like.

2. The acceptor's responsibility.-The purpose of commercial standards is to establish for specific commodities, nationally recognized grades or consumer criteria and the benefits therefrom will be measurable in direct proportion to their general recognition and actual use. Instances will occur when it may be necessary to deviate from the standard and the signing of an acceptance does not preclude such departures; however, such signature indicates an intention to follow the commercial standard where practicable, in the production, distribution, or consumption of the article in question.

3. The Department's responsibility.-The major function performed by the Department of Commerce in the voluntary establishment of commercial standards on a Nation-wide basis is fourfold: first, to act as an unbiased coordinator to bring all interested parties together for the mutually satisfactory adjustment of trade standards; second, to supply such assistance and advice as past experience with similar programs may suggest; third, to canvass and record the extent of acceptance and adherence to the standard on the part of producers, distributors, and users; and fourth, after acceptance, to publish and promulgate the standard for the information and guidance of buyers and sellers of the commodity.

4. Announcement and promulgation.-When the standard has been endorsed by a satisfactory majority of production or consumption in the absence of active, valid opposition, the success of the project is announced. If, however, in the opinion of the standing committee or the Department of Commerce, the support of any standard is inadequate, the right is reserved to withhold promulgation and publication. 


\section{ACCEPTORS}

15.1 The organizations and individuals listed below have accepted this commercial standard as their standard of practice in the production, distribution, purchase, and testing of warm air furnaces equipped with vaporizing pot-type oil burners. Such endorsement does not signify that they may not find it necessary to deviate from the standard, nor that producers so listed guarantee all of their products in this field to conform with the requirements of this standard. Therefore, specific evidence of conformity should be obtained where required.

\section{ASSOCIATIONS}

(General Support)

American Institute of Architects, Washington, D. C. Heating, Piping \& Air Conditioning Contractors Association, Cleveland, Ohio.

Heating, Piping \& Air Conditioning Contractors District of Columbia Association, Inc., Washington, D. C.

National Association of Purchasing Agents, Carteret, N. J.

National Warm Air Heating \& Air Conditioning Association, Minneapolis, Minn.

Oil-Heat Institute of A merica, Inc., New York, N. Y. Producers Council, Inc., The, Washington, D. C.

\section{FIRMS}

Aahmes Burner Co., Washington, D. C.

Ackerman, Frederick L.-Charles G. Ramsey \& Harold R. Sleeper, Associates, New York, N. Y. Adams, Franklin O., Tampa, Fla.

Alcar Supply Co., Inc., Rochester, $\mathrm{N}$. Y.

Allied Distributing Corporation, Norfolk, Va.

American Furnace \& Foundry Co., The, Milan, Mich.

American Houses, Inc., New York, N. Y.

American Oil Burner Co., Los Angeles, Calif.

American Stove Co., Lorain, Ohio.

Anchor Appliances, Inc., Tampa, Fla.

Arrow Petroleum Co., Forest Park, Ill.

Atwater Fuel Corporation, New York, N. Y.

Austin, Ennis R., South Bend, Ind.

Automatic Products Co., Milwaukee, Wis.

Bacharach Industrial Instrument Co., Pittsburgh $\mathrm{Pa}$.

Baltimore, City of, Bureau of Plans \& Surveys, Baltimore, Md.

Barthmaier, Eugene V., Philadelphia, Pa.

Baumer, Herbert, Columbus, Ohio.

Bennett Oil Co., Omaha, Nebr.

Berger \& Kelley, Champaign, Ill.

Berkshire Sheet Metal Works, Inc., Pittsfield, Mass. Bettcher, Geo. L., Denver, Colo.

Better Living Co., Jackson, Miss.

Beuttler, William, Sioux City, Iowa.

Blithe, Wesley Lesher, Philadelphia, Pa.

Boehm, George A., New York, N. Y.

Borg-Warner Corporation, Ingersoll Steel Division, Kalamazoo, Mich.

Borg-Warner Corporation, Norge Heating \& Conditioning Division, Detroit, Mich.

Bourne \& Son, M. B., Portland, Maine.

Bovard, William R., Kansas City, Mo. (General support).

Brazer, Clarence W., New York, N. Y.

Brooks-Borg, Des Moines, Iowa.

Brust \& Brust, Milwaukee, Wis.

Bucky, Fred W., Jr., Jacksonville, Fla.

Bull, Ralph N., Sparta, N. J.
Burns Supply Co., Long Island City, N. Y.

Cannon \& Mullen, Salt Lake City, Utah.

Carroll, John, Atlantic City, N. J.

Century Engineering Corporation, Cedar Rapids, Iowa.

Chapin, Rollin C., Minneapolis, Minn. (General support.)

Chrysler Corporation, Airtemp Division, Dayton, Ohio.

Cincinnati, City of, Cincinnati, Ohio.

Cleveland Board of Education, Cleveland, Ohio.

Coleman Co., Inc., The, Wichita, Kans.

Columbus Metal Products, Inc., Columbus, Ohio.

Conrad \& Cummings, Associated Architects, Bing. hamton, N. Y.

Consumers Heating Equipment Co., Inc., Baltimore, $\mathrm{Md}$.

Consumers Petroleum Co., Chicago, Ill.

Coroaire Heater Corporation, The, Cleveland, Ohio.

Corriveaux, F.-Home \& Industrial Service, Schenectady, N. Y.

Cotta Transmission Co., Rockford, Ill.

Cram \& Ferguson, Boston, Mass.

Cronstrom Heating \& Sheet Metal, Minneapolis, Minn.

Crump Co., Inc., B. T., Richmond, Va.

Cunningham \& Son, A. B., Baltimore, Md.

Currier Lumber Co., Detroit, Mich.

Curtsinger, L. P., Eugene, Oreg.

Dallman Supply Co., Sacramento, Calif.

Deal \& Son, Kalamazoo, Mich.

DeJarnette, Charles Wagner, Des Moines, Iowa.

Delta-Star Electric Co., Chicago, Ill.

Detroit, University of, Detroit, Mich.

Dodge Corporation, F. W., Sweet's Catalog Service,

Chicago, Ill.

Domestic Co., Seattle, Wash.

Eastern Oil Co., Inc., Worcester, Mass.

Elliott-Lewis Co., Inc., Philadelphia, Pa.

English, Miller \& Hockett, Hutchinson, Kans.

Erdelen, Arthur F., St. Louis, Mo. (General sup. port).

Estate Stove Co., The, Hamilton, Ohio.

Evans Products Co., Detroit, Mich.

Excelsior Stove \& Manufacturing Co., Quincy, Ill.

Fargo Foundry Co., Fargo, N. Dak.

Farrington Co., T. D., Seattle, Wash.

Fisher Electrical Service, Union, N. J.

Flannagan, Eric G., Henderson, N. C.

Ford Luinber Co., Ivon R., MeDonough, N. Y.

Gibb, Office of Arthur N., Ithaca, N. Y.

Griffin Iumber Co., Glens Falls, N. Y.

Hahn, Stanley W., S. Pasadena, Calif.

Haldeman, Inc., Harry F., Los Angeles, Calif.

Hall Bros. Oil Co., Dayton, Ohio.

Harris, Jay, New York, N. Y.

Hasness, Carlisle D., Harrisburg, Pa.

Heating Distributors Co., La Crosse, Wis.

Heating Supply Co., Inc., Rochester, N. Y.

Heil Co., The, Milwaukee, Wis.

Helfensteller, Hirsch \& Watson, St. Louis, Mo. 
Herlan-Patterson, Inc., Buffalo, N. Y.

Hodgdon, Charles, San Gabriel, Calif.

Holland Furnace Co., Holland, Mich.

Holsman \& Holsman \& Klekamp, Chicago, Ill.

Horley, Ed F., Ingram, Pa.

Hospital Consultants, Chicago, Ill.

Illinois Farm Supply Co., Kingston Mines, Ill (General support).

Illinois, University of, Department of Architecture,

Urbana, Champaign, Ill. (General support).

International Oil Burner Co., St. Louis, Mo.

Johnson Co., J. D., Pensacola, Fla.

Kahn Associated Architects \& Engineers, Inc., Albert, Detroit, Mich.

Keich \& O'Brien, Warren, Ohio.

Kelley, Frederic P., Miliington, N. J.

Korth Oil Burner Corporation, Roselle Park, N. J

Kresky Manufacturing Co., Inc., Petaluma, Calif.

Kresno Stamm Manufacturing Co., New York, N. Y.

Kyle, Herbert S., Charleston, W. Va. (General support).

Laco Oil Burner Co., Griswold, Iowa.

Larrick, Thomas, Athens, Ohio.

Latenser \& Sons, John, Omaha, Nebr.

Law, Law, Potter \& Nystrom, Madison, Wis.

Leff Engineering Co., Mobile, Ala.

Leidy Electric Co., Air Conditioning \& Heating Division, Phillipsburg, N. J.

Levy, Will, St. Louis, Mo.

Lewiston Hardware \& Plumbing Supply Co., Lewiston, Maine.

Lincoln Oil Co., Boston, Mass.

Lippert, Grover H., Madison, Wis.

Little Burner Co., Inc., H. C., San Rafael, Calif. and Chicago, Ill.

Loeb, Laurence M., White Plains, N. Y.

Lonergan Manufacturing Co., Albion, Mich.

Lowry Electric Co., Inc., Williamsport, $\mathrm{Pa}$.

Macleod, L., Pasadena, Calif.

Madigan \& Hyland, Long Island City, N. Y.

Mann \& Co., Hutchinson, Kans.

Mansfield Co., Inc., Norfolk, Va.

Marshall-Wells Co., Duluth, Minn., and Portland, Oreg.

Martino Co., A. R., Waterbury, Conn.

Mason \& Co., George D., Detroit, Mich

Massena \& duPont, Wilmington, Del.

Matthews Engineering Co., Dallas, Tex.

Mauran, Russell, Crowell \& Mullgradt, st. Louis, Mo.

May Oil Burners Sales Co., Milwaukee, Wis.

McDougall Co., John W., Nashville, Tenn.

MeMahill Heating Service, Omaha, Nebr.

Metropolitan Petroleum Co., Inc., Bethesda, Md.

Michigan Tank \& Furnace Corporation, Detroit, Mich.

Mid-States Industrial Corporation, Rockford, Ill.

Miller \& Yeager, Terre Haute, Ind.

Minneapolis, City of, Department of Buildings, Minneapolis, Minn.

Minnesota, University of, Engineering Experiment Station, Minneapolis, Minn

Mitchell Sales Corporation, Bremerton, Wash.

Monroe Air Conditioning Co., Inc., Rochester, N. Y

Montgomery Ward \& Co., Chicago, Ill.

Mooser, William, San Francisco, Calif.

Morley-Murphy Co., Milwaukee, Wis.

Mormile Wholesale Plumbing \& Heating Supplies, Amsterdam, N. Y.

Motor Wheel Corporation, Duotherm Division, Lansing, Mich.

Mueller Furnace Co., L. J., Milwaukee, Wis.

Mueller-Hair \& Hetterich, Hamilton, Ohio.

Nelson, Albert L., St. Louis, Mo.

New Orleans, Inc., Better Business Bureau of, New Orleans, La. (General support).

New York, City of, Department of Purchase, New York, N. Y

New York Telephone Co., Upstate Area, Albany, N. Y.

Noland Co., Inc., Newport News, Va.

North Dakota Agricultural College, School of Engineering, Fargo, N. Dak.
Officer, Gwynn, Berkeley, Calif.

Oil Devices, Chicago, Ill. (General support).

Oil Heat Utilities of Long Island, Inc., New York, N. Y.

Oklahoma, University of, Norman, Okla.

Orange Memorial Hospital, Orange, N. J. (General support).

Orth, H. W., St. Paul, Minn.

Orton Heating Co., The, Barberton, Ohio,

Pacific Coast Heating \& Appliance Co., Portland, Oreg.

Pacific Supply Co-operative, Walla Walla, Wash.

Pehrson \& Associates, G. A., Spokane, Wash.

Peirce-Phelps, Inc., Philadelphia, $\mathrm{Pa}$

Pepper, George W., Jr., Philadelphia, Pa.

Perfect Air Conditioning Co., Washington, D. C.

Perfection Stove Co., Cleveland, Ohio.

Prentiss Wabers Products Co., Wisconsin Rapids, Wis.

Purdue University, Lafayette, Ind.

Rackliffe Oil Co., The, New Britain, Conn.

Reid, William H., Jr., Billings, Mont.

Rhodes, Harry A., Rensselaer, N. Y. (General support).

Ritchie \& Associates, James H., Boston, Mass.

Robinson Furnace Co., Chicago, Ill.

Rochester, City of, Board of Education, Rochester, N. Y.

Rochester Fire Bureau, Fire Prevention Section, Rochester, N. Y

Rockwell Co., W. S., (Industrial Heating Engineers), New York, N. Y.

Roslyn Supply Co., Roslyn, L. I., N. Y.

Ryan, Ernest J., Boston, Mass.

Schulzke, William H., Moline, Ill.

Schuylkill Valley Oil Co., Pottstown, $\mathrm{Pa}$

Scobell Co., G. L., Erie, Pa.

Sears, Roebuck \& Co., Chicago, Ill.

Silent Sioux Oil Burner Corporation, Orange City, Iowa.

Smith, Hinchman \& Grylls, Detroit, Mich.

Southwest Heating \& Cooling Co., Wichita, Kans. Sprinchorn \& Co., Jamestown, N. Y.

Springfield Lumber Supply Co., Springfield, Mo.

Standard Oil Co. of California, San Francisco, Calif.

Standard Utilities Corporation, Newark, N. J.

Staub \& Rather, Houston, Tex.

Stoetzel, Ralph, Chicago, Ill.

Streeter, Daniel D., Brooklyn, N. Y.

Sunland Refining Corporation, Fresno, Calif.

Susquehanna Supply Co., Williamsport, $\mathrm{Pa}$

Swarthmore Heating Service, Swarthmore, Pa.

Taylor, Ellery K., Haddonfield, N. J.

Temple, Seth J.,-Arthur Temple, Davenport, Iowa.

Tharp \& Son, Chas. E., Fort Wayne, Ind.

Thatcher Furnace Co., Garwood, N. J.

Thorne, Henry Calder, Ithaca, N. Y.

Thurman \& Boone Co., Inc., Roanoke, Va.

Underwriters' Laboratories, Inc., Chicago, Ill.

United States Testing Co., Inc., Hoboken, N. J. (General support).

Utility Appliance Corporation, Los Angeles, Calif. Viking Manufacturing Corporation, Dayton, Ohio. Virginia Polytechnic Institnte, Blacksburg, Va.

Walsh, Louis A., Waterbury, Conn.

Ware \& McClenahan, Salt Lake City, Utah.

Welch, Carroll E., Huntington, N. Y.

West, Albert E, Boston, Mass.

White Fuel Corporation, S. Boston, Mass.

White-Rodgers Electric Co., St. Louis, Mo.

Willatsen, Andrew, Seattle, Wash.

Winter Co., G. C., Southbridge, Mass.

Wright \& Wright, Detroit, Mich

Zimmerman, A. C., Pasadena, Calif.

\section{U. S. GOVERNMENT}

A griculture, U. S. Department of, Washington, D. C. Federal Housing Administration, Washington, D. C. Federal Public Housing Authority, Washington, D. C Navy Department, Bureau of Yards \& Docks, Washington, D.C

War Department, Washington, D. C. 


\section{COMMERCIAL STANDARDS}

CS No.

Item

0-40. Commercial standards and their value to business (third edition).

1-42. Clinical thermometers (third edition).

2-30. Mopsticks.

3-40. Stoddard solvent (third edition).

4-29. Staple porcelain (all clay) plumbing fixtures.

5-46. Pipe nipples; brass, copper, steel, and wrought-iron (second edition).

6-31. Wrought-iron pipe nipples (second edition). Superseded by CS5-46.

7-29. Standard weight malleable iron or steel screwed unions.

8-41. Gage blanks (third edition).

9-33. Builders' template hardware (second edition).

10-29. Brass pipe nipples. Superseded by CS546.

11-41. Moisture regains of cotton yarns (second edition)

12-40. Fuel oils (fifth edition).

13-44. Dress patterns (fourth edition)

14-43. Boys' button-on waists, shirts, junior and sport shirts (made from woven fabrics) (third edition).

15-46. Men's pajamas (made from woven fabrics) (third edition).

16-29. Wall paper.

17-42. Diamond core drill fittings (third edition)

18-29. Hickory golf shafts.

19-32. Foundry patterns of wood (second edition).

20-42. Staple vitreous china plumbing fixtures (third edition).

21-39. Interchangeable ground-glass joints, stopcocks, and stoppers (fourth edition).

22-40. Builders' hardware (nontemplate) (second edition).

23-30. Feldspar.

24-43. Screw threads and tap-drill sizes.

25-30. Special screw threads. Superseded by C S24-43.

26-30. Aromatic red cedar closet lining.

27-36. Mirrors (second edition).

28-46. Cotton fabric tents, tarpaulins, and covers (second edition).

29-31. Staple seats for water-closet bowls.

30-31. Colors for sanitary ware.

31-38. Wood shingles (fourth edition).

$32-31$. Cotton cloth for rubber and pyroxylin coating.

33-43. Knit underwear (exclusive of rayon) (second edition)

34-31. Bag, case, and strap leather.

35-42. Plywood :(hardwood and eastern red cedar) (second edition).

36-33. Fourdrinier wire cloth (second edition).

37-31. Steel bone plates and screws.

38-32. Hospital rubber sheeting.

39-37. Wool and part wool blankets (second edition). (Withdrawn as commercial standard, July 14, 1941).

40-32. Surgeons' rubber gloves.

41-32. Surgeons' latex gloves.

42-43. Structural fiber insulating board (third edition)

43-32. Grading of sulphonated oils.

44-32. A pple wraps.

45-45. Douglas fir plywood (sixth edition).

46-40. Hosiery lengths and sizes (third edition).

47-34. Marking of gold-filled and rolled-goldplate articles other than watcheases.

48-40. Domestic burners for Pennsylvania anthracite (underfeed type) (second edition)

49-34. Chip board, laminated chip board, and miscellaneous boards for bookbinding purposes.
CS No.

Item

50-34. Binders board for bookbinding and other purposes.

51-35. Marking articles made of silver in combination with gold.

52-35. Mohair pile fabries (100-percent mohair plain velvet, 100 -percent mohair plain frieze, and 50-percent mohair plain frieze).

53-35. Colors and finishes for cast stone.

54-35. Mattresses for hospitals.

55-35. Mattresses for institutions.

56-41. Oak flooring (second edition).

57-40. Book cloths, buckrams, and impregnated fabries for bookbinding purposes except library bindings (second edition).

$58-36$. Woven elastic fabries for use in overalls (overall elastic webbing).

59-44. Textiles-testing and reporting (fourth edition).

60-36. Hardwood dimension lumber.

61-37. Wood-slat venetian blinds.

62-38. Colors for kitchen accessories.

63-38. Cloors for bathroom accessories.

64-37. Walnut veneers.

65-43. Methods of anlaysis and of reporting fiber composition of textile products (second edition)

66-38. Marking of articles made wholly or in part of platinum.

67-38. Marking articles made of karat gold.

68-38. Liquid hypochlorite disinfectant, deodorant, and germicide.

69-38. Pine oil disinfectant.

70-41. Phenolic disinfectant (emulsifying type) (second edition) (published with CS71-41).

71-41. Phenolic disinfectant (soluble type) (second edition) (published with CS70-41).

72-38. Household insecticide (liquid spray type).

73-45. Old growth Douglas fir standard stock doors (third edition).

74-39. Solid hardwood wall paneling.

75-42. Automatic mechanical draft oil burners designed for domestic installations (second edition).

76-39. Hardwood interior trim and molding.

77-40. Sanitary cast-iron enameled ware.

78-40. Ground-and-polished lenses for sun glasses (second edition) (published with CS79-40).

79-40. Blown, drawn, and dropped lenses for sun glasses (second edition) (published with SC78-40).

80-41. Electric direction signal systems other

\& than semaphore type for commercial and other vehicles subject to special motor vehicle laws (after market).

81-41. Adverse-weather lamps for vehicles (after market).

82-41. Inner-controlled spotlamps for vehicles (after market)

83-41. Clearance, marker, and identification lamps for vehicles (after market).

84-41. Electric tail lamps for vehicles (after market).

85-41. Electric license-plate lamps for vehicles (after market).

86-41. Electric stop lamps for vehicles (after market).

87-41. Red electric warning lanterns,

88-41. Liquid-burning flares.

89-40. Hardwood stair treads and risers.

90- (Reserved for power shovels and cranes).

91-41. Factory-fitted Douglas fir entrance doors. 
CS No.

Item

92-41. Cedar, cypress, and redwood tank stock lumber.

93-41. Portable electric drills (exclusive of high frequency).

94-41. Calking lead.

95-41. Lead pipe.

96-41. Lead traps and bends.

97-42. Electric supplementary driving and passing lamps for vehicles (after market).

98-42. Artists' oil paints.

99-42. Gas floor furnaces-gravity circulating type.

100-44. Porcelain-enameled stcel utensils (second edition).

101-43. Flue-connected oil-burning space heaters equipped with vaporizing pot-type burners.

102- . (Reserved for Diesel and fuel-oil engines.)

103-42. Cotton and rayon velour (jacquard and plain).

104-46. Warm-air furnaces equipped with vaporizing pot-type oil burners (second edition).

105-43. Mineral wool; loose, granulated, or felted form, in low-temperature installations.

106-44. Boys' pajama sizes (woven fabries) (second edition).

107-45. Commercial electric-refrigeration condensing units (second edition).

108-43. Treading automobile and truck tires.

109-44. Solid-fuel-burning forced-air furnaces.

110-43. Tire repairs-vulcanized (passenger, truck, and bus tires).

111-43. Earthenware (vitreous-glazed) plumbing fixtures.
CS No.

Item

112-43. Homogeneous fiber wallboard.

113-44. Oil-burning floor furnaces equipped with vaporizing pot-type burners.

114-43. Hospital sheeting for mattress protection.

115-44. Porcelain-enameled tanks for domestic use.

116-44. Bituminized-fibre drain and sewer pipe.

117-44. Mineral wool; blankets, blocks, insulating cement, and pipe insulation for heated industrial equipment.

118-44. Marking of jewelry and novelties of silver.

(E)119-45, 1 Dial indicators (for linear measurements).

120-44. Standard stock ponderosa pine doors

121-45. Women's slip sizes (woven fabrics)

122-45. Western hemlock plywood.

123-45. Grading of diamond powder.

(E) 124-45. ${ }^{1}$ Master disks.

125-45. Prefabricated homes.

126-45. Tank-mounted air compressors.

127-45. Self-contained mechanically refrigerated drinking water coolers.

128-45. Men's sport shirt sizes-woven fabrics (other than those marked with regular neckband sizes).

129-46. Materials for safety wearing apparel.

130-46. Color materials for art education in schools.

131-46. Industrial mineral wool products, all types-testing and reporting.

132-46. Hardware cloth

133-46. Woven wire netting.

134- . (Reserved)

135-46. Men's shirt sizes.

1 Where "(E)" precedes the CS number, it indicates an emcrgency commercial standard, drafted under war conditions with a view toward carly revision.

Notice.-Those interested in commercial standards with a view toward accepting them as a basis of everyday practice may secure copies of the above standards, while the supply lasts, by addressing the Division of Trade Standards, National Bureau of Standards, Washington 25, D. C. 